\title{
Education 4.0 Made Simple: Ideas For Teaching
}

\author{
Anealka Aziz Hussin* \\ Akademi Pengajian Bahasa, Universiti Teknologi MARA (UiTM) \\ Corresponding author: Anealka Aziz Hussin, E-mail: anealka@salam.uitm.edu.my
}

\section{ARTICLE INFO}

Article history

Received: April 26, 2018

Accepted: July 29, 2018

Published: July 31, 2018

Volume: 6 Issue: 3

Conflicts of interest: None

Funding: None

\begin{abstract}
Almost everyone is talking about the $4^{\text {th }}$ Industrial Revolution (4IR). The 4IR wave is so strong that change is inevitable, including within the education setting, making Education 4.0 the famous buzzword among educationists today. What is Education 4.0? Do educators really understand it or they simply follow what others are doing. Education 4.0 is a respond to the needs of IR4.0 where human and technology are aligned to enable new possibilities. The paper explains the nine trends of Education 4.0, preference of the $21^{\text {st }}$ century learners, skills for $21^{\text {st }}$ century teachers, share some ideas on how to implement Education 4.0 trends in the language classrooms and students' feedback on their experience in learning in the Education 4.0 classroom.
\end{abstract}

Key words: Industrial Revolution 4.0, Education 4.0, Language Teaching And Learning

\section{INTRODUCTION}

The famous buzzword among educationists today is Education 4.0. What is Education 4.0? Do educators really understand it or they simply follow what others are doing. To understand Education 4.0, it is important to understand the Industrial Revolution (IR) 4.0.

What is Industrial Revolution (IR) 4.0? Shwab (2016) provides an example that helps to understand how the industrial revolutions changed across time. During the $1^{\text {st }} I R$, water and steam were used to mechanize production. During the $2^{\text {nd }} I R$, electric power was used to create mass production. During the $3^{\text {rd }} \mathrm{IR}$, electronics and information technology were used to automate production. The $4^{\text {th }} \mathrm{IR}$ is beyond an enhancement of the $3^{\text {rd }} \mathrm{IR}$, in which the advancement of new technologies blurs the lines between the physical, digital and biological worlds. The new technologies evolve at exponential pace and there is no historical precedent that marked the beginning of the evolution, hence being called disruptive technologies. These advancements are led by the emergence of artificial intelligence, robotics, the internet of things, autonomous vehicles, bio and nanotechnology, 3-D printing, material science, quantum computing and energy storage (Diwan, 2017). The IR 4.0 affects not only the business, governance and the people, it also affects education as well, thus the name Education 4.0 came to existence.

Education 4.0 is a response to the needs of IR4.0 where human and technology are aligned to enable new possibilities. Fisk (2017) explains that the new vision of learning promotes learners to learn not only skills and knowledge that are needed but also to identify the source to learn these skills and knowledge. Learning is built around them as to where and how to learn and tracking of their performance is done through data-based customization. Peers become very significant in their learning. They learn together and from each other, while the teachers assume the role of facilitators in their learning.

There are nine trends related to Education 4.0 (Fisk, 2017). First, learning can be taken place anytime anywhere. e-Learning tools offer great opportunities for remote, selfpaced learning. Flipped classroom approach also plays a huge role as it allows interactive learning to be done in class, while the theoretical parts to be learned outside the class time.

Second, learning will be personalized to individual students. They will be introduced to harder tasks only after a certain mastery level is achieved. More practices will be provided if the instructors see a need in it. Positive reinforcements are used to promote positive learning experience and boost students' confidence about their own academic abilities.

Third, students have a choice in determining how they want to learn. Although the learning outcomes of a course are preset by the institutions/bodies in charge of the curriculum, students are still free to choose the learning tools or techniques that they prefer. Among the options that lecturers can adopt to enable students to be creative in their learning are blended learning, flipped classroom and BYOD (Bring Your Own Device) approach.

Fourth, students will be exposed to more project-based learning. Students are required to apply their knowledge and skills in completing a couple of short term projects. By involving in the projects, they are practicing their organizational, collaborative and time management skills which are useful in their future academic careers. 
Fifth, students will be exposed to more hands-on learning through field experience such as internships, mentoring projects and collaborative projects. The advancement of the technology enables the learning of certain domains effectively, thus making more room for acquiring skills that involve human knowledge and face-to-face interaction.

Sixth, students will be exposed to data interpretation in which they are required to apply their theoretical knowledge to numbers and use their reasoning skills to make inferences based on logic and trends from given sets of data. The manual part of mathematical literacy will become irrelevant as computers will perform the statistical analysis and predict the future trends.

Seventh, students will be assessed differently and the conventional platforms to assess students may become irrelevant or insufficient. Students' factual knowledge can be assessed during the learning process, while the application of the knowledge can be tested when they are working on their projects in the field.

Eighth, students' opinion will be considered in designing and updating the curriculum. Their inputs help the curriculum designers maintain curriculum contemporariness, up-todate and usefulness.

Lastly, students will become more independent in their own learning, thus forcing teachers to assume a new role as facilitators who will guide the students through their learning process.

The nine trends of Education 4.0 shift the major learning responsibilities from the instructors to the learners. Instructors should play their roles to support the transition and should never consider it a threat to the conventional teaching profession.

\section{Education 4.0 in Malaysia}

Dunwill (2016) says that the advancement of technologies keeps on changing and transforming the teaching method and the setting of the learning process. In fact, there will be more changes in the future. Some of the common changes that have been embraced by institutions includes lecturers post students' grades and assignment online, students use collaborative software/application to complete group tasks, students complete their assignments online and upload them in an online class portal or the institution learning management system, students' high dependency on cloud storage to store their work and communication among students, parents, lecturers and administration is done via social media platforms.

Dunwill (2016) also predicted how an average classroom will look like in the next 5 to 7 years.

a) A huge change in the layout of the classroom

b) Virtual and augmented reality will change the educational landscape

c) Flexible assignments will accommodate multiple learning styles

d) MOOC and other online learning options will impact secondary education

Dunwill (2016) focuses on the changes that will take place in the teaching method and the setting of the learning process for the secondary education in the next 5 to 7 years. Similar transformation has already taken place in the tertiary education setting in Malaysia. Layout of the classroom has gradually changed from neat rows and chairs to flexible seating arrangement enabling for both individual and collaborative workspaces. Student assignments are no longer in the form of constructed or selected responses only. Alternative assessments have been introduced to accommodate multiple learning styles. Portfolio, project papers, demonstration of skills and rating scales are among the alternative assessments being practiced nowadays. Apart from changes in the classroom layout and the types of assessment, the tertiary education has started using Massive Open Online Courses (MOOCs) and other online learning platforms in the teaching and learning.

Most of the MOOCs offered by prestigious academic institutions in Malaysia are free. Students can choose any courses that they are interested. Many courses are self-paced, enabling the students to learn the courses anytime, anywhere convenient to them using devices of their choice. Students can register in Malaysia MOOC by going to this website: https://www.openlearning.com/malaysiamoocs.

Lastly, Dunwill's (2016) final prediction related to the use of virtual reality (VR) and augmented reality (AR) in teaching and learning seems rather new to many instructors in the tertiary education in Malaysia. The emergence of user-friendly VR and AR apps has helped instructors to integrate virtual and augmented reality in their teaching and learning.

\section{Preference of the $21^{\text {st }}$ Century Learners}

The present tertiary students aged between 18 to 23 years old and they belong to the Generation $-\mathrm{Z}$ (Gen Z) who are so revolutionized by technology. The learning preference of the Gen $\mathrm{Z}$ students are different students from the previous generation as they are more hands-on and directly involved in the learning process. Kozinski (2017) highlighted the following learning preferences of the Gen $\mathrm{Z}$ students. The Gen $\mathrm{Z}$ students are those who are fully engaged in their learning process. They welcome challenges and enjoy group discussion and highly interactive learning environment. For them, learning is without boundaries; they can learn anywhere and anytime and have unlimited access to new information. Leaning that involves active collaboration with their team members and learning at places other than their classroom interest them. On top of that, the use of digital tools and online forums are preferred as they prefer them to be integrated in their learning process. Since the Gen $\mathrm{Z}$ students are so much into the digital tools, they expect the tools are available whenever they need them with at low access barriers. These Gen $\mathrm{Z}$ students need to be prepared to thrive in the Fourth Industrial Revolution. Figure 1 shows the top 10 skills as reported in The World Economic Forum that students need to have in 2020 World Economic Forum, 2016a).

\section{Strategies for Conducive Learning Environment}

Based on the World Economic Forum report on Social and Emotional Learning (SEL) (World Economic Forum, 
$2016 \mathrm{~b}$ ), there are 16 crucial proficiencies for education in the $21^{\text {st }}$ century which are grouped into Foundational Literacies, which deal with how students apply core skills to everyday tasks, Competencies, which deal with how students approach complex challenges and Character Qualities, which deal with how students approach their changing environment. The report lists 14 strategies that can create a conducive learning environment to support SEL. These strategies can help students develop their collaborative, communicative and problem-solving skills (Soffel, 2016). The list of the strategies is displayed in Figure 2. Having incorporated the strategies, students are hoped to have better character qualities such as having social and cultural awareness, leadership skills, be more adaptive, persistence and initiative. Besides character qualities, students are also hoped to acquire competencies related to problem-solving/critical thinking skills, creativity, communication, and collaboration.

\section{Becoming the $21^{\text {st }}$ Century Instructors}

Instructors need to relearn and equip themselves with the digital tools to meet the learning preference of the Gen $\mathrm{Z}$ students. There are many digital tools available online that instructors can choose from. Educational Technology and Mobile Learning (2016) website suggested instructors to

\section{Top 10 Skills in 2020 \\ 1. Complex Problem Solving \\ 2. Critical Thinking \\ 3. Creativity \\ 4. People Management \\ 5. Coordinating with Others \\ 6. Emotional Intelligence \\ 7. Judgement and Decision Making \\ 8. Service Orientation \\ 9. Negotiation \\ 10. Cognitive Flexibility}

Source: The future of jobs and skills, World Economic Forum

Figure 1: Top 10 Skills in 2020

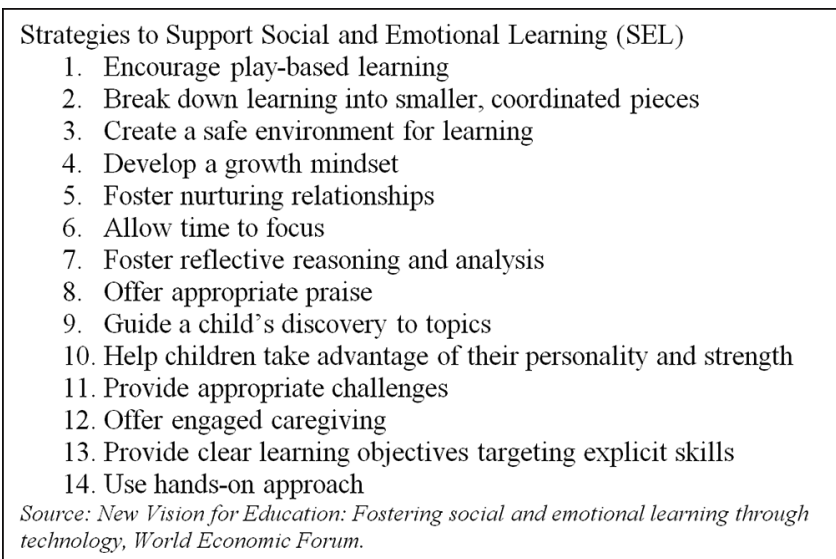

Figure 2: Strategies to Support SEL equip themselves with these nine fundamental digital skills as shown in Table 1.

\section{Sharing Session}

One of the English language courses offered at the institution the author is currently attached is selected to illustrate how digital technology can be integrated in the teaching and learning of the course to meet the preference of the Gen $\mathrm{Z}$ learners, support the SEL and training them to acquire the skills listed in the top 10 skills in 2020 .

The course is taught using the flipped classroom approach where learning of the content is done independently outside the class time and learning activities are conducted during the class time. OpenLearning (OL) platform which is a social learning platform, is used to host the content, tasks and assessment of the course. Figure 3 shows the interface of the content of the course in OL platform.

Prior to using the platform, a course briefing is conducted to inform students about the objectives of the course, approach used to teach the course, how to use the platform and other matters related to the administration of the course.

Content of the course is prepared earlier. However, additional materials and activities can be added from time to time depending on the learning needs of the students. The content can be in the form of videos, pdf slides, texts and links to related websites and it is broken down into sub-topics to facilitate learning. Figure 4 shows the learning activities for one of the modules in the course.

Tasks related to the content are also uploaded in the same platform. Students need to complete the tasks before they come to class as these tasks may be needed for onsite activities.

The course begins with a task called Analyze Yourself. The students are required to perform a self-analysis of their strengths and weaknesses and determine the top three professional attributes that will get them hired by employers. An application called Mentimeters, an interactive presentation software (https://www.mentimeter.com) is used to elicit responses from the students. Students must go to Mentimeters Voting (https://www.menti.com/) to type the three professional attributes that will get them hired by employers. Figure 5 shows the interface of Mentimeters Voting and the output of the voting in the form of a word cloud. The size of the words depends on the frequency the words are being typed by the students. In this example, HARDWORKING is the top personality trait that will get the students hired. It is followed by CONFIDENT and INDEPENDENT.

The next activity was a group activity. The students are required to search for a job using the online job search engines in Malaysia. Some of the job search engines are listed in Table 2.

Students are asked to find a job and analyze the information in the job description and job requirements provided by the company. The students discuss the personal attributes of potential candidates and the types of skills the candidates need to increase the success rate of the application. A free online bulletin board called Padlet (https://padlet.com/) was used for this purpose. Padlet allows users to collaborate, 
Table 1: Nine fundamental digital skills for instructors

\begin{tabular}{|c|c|c|c|}
\hline Digital skills & Tools & & \\
\hline Record and edit audio clips & $\begin{array}{l}\text { Soundcloud } \\
\text { audioboo }\end{array}$ & $\begin{array}{l}\text { Vocaroo } \\
\text { clyp }\end{array}$ & \\
\hline Create annotated, interactive and engaging video content & $\begin{array}{l}\text { Blubbr } \\
\text { Magisto } \\
\text { Teachem }\end{array}$ & $\begin{array}{l}\text { TED Ed } \\
\text { Edpuzzle } \\
\text { Wevideo }\end{array}$ & $\begin{array}{l}\text { Videonotes } \\
\text { YouTube video editor }\end{array}$ \\
\hline Create visually engaging content & $\begin{array}{l}\text { Piktochart } \\
\text { Canva }\end{array}$ & $\begin{array}{l}\text { Glogster } \\
\text { Thinglink }\end{array}$ & Google draw \\
\hline $\begin{array}{l}\text { Use social networking websites to create PLNs, connect, discover new } \\
\text { content, and grow professionally }\end{array}$ & $\begin{array}{l}\text { Twitter } \\
\text { Facebook }\end{array}$ & $\begin{array}{l}\text { Google Plus } \\
\text { LinkedIn }\end{array}$ & \\
\hline Use blogs and wikis to create participatory spaces for students & $\begin{array}{l}\text { Blogger } \\
\text { WordPress }\end{array}$ & $\begin{array}{l}\text { Kidblog } \\
\text { Wikispaces }\end{array}$ & $\begin{array}{l}\text { Edublog } \\
\text { Weebly }\end{array}$ \\
\hline Use social bookmarking websites curate and share resources with your class & $\begin{array}{l}\text { Diigo } \\
\text { Scoop.it }\end{array}$ & $\begin{array}{l}\text { Edshelf } \\
\text { Educlipper }\end{array}$ & $\begin{array}{l}\text { Pinterest } \\
\text { Symbaloo }\end{array}$ \\
\hline Create engaging presentations & $\begin{array}{l}\text { Prezi } \\
\text { Haiku Deck }\end{array}$ & $\begin{array}{l}\text { Google Slide } \\
\text { Zoho Presen }\end{array}$ & \\
\hline Create digital portfolios & $\begin{array}{l}\text { SeeSaw } \\
\text { Pathbrite }\end{array}$ & $\begin{array}{l}\text { Silk } \\
\text { Weebly }\end{array}$ & Google sites \\
\hline Create non-traditional quizzes & $\begin{array}{l}\text { Testmoz } \\
\text { Quizalize }\end{array}$ & $\begin{array}{l}\text { Riddle } \\
\text { QuizBean }\end{array}$ & Flipquiz \\
\hline
\end{tabular}

Table 2: Samples of Job search engines

\begin{tabular}{|c|c|}
\hline 1. ReferJobs.my (http://referjobs.my/) & 1. MauKerja (https://www.maukerja.my/) \\
\hline 2. JobStreet (https://www.jobstreet.com.my/) & 2. Monster (http://www.monster.com.my/) \\
\hline 3. WOBB (https://my.wobb.co/) & 3. Graduan (https://graduan.com/) \\
\hline 4. JoBi (http://www.jobi.co/) & 4. careerJET (https://www.careerjet.com.my/) \\
\hline 5. TribeHired (https://tribehired.com/splash/user) & 5. jobstore (https://www.jobstore.com/my) \\
\hline 6. Startup Jobs in Asia (http://www.startupjobs.asia/) & 6. hiredNOW (https://www.hirednow.com.my/) \\
\hline 7. WowIntro (https://wowintro.me/) & 7. HAYS (https://www.hays.com.my/) \\
\hline 8. Intern.my (https://intern.my/) & \\
\hline
\end{tabular}

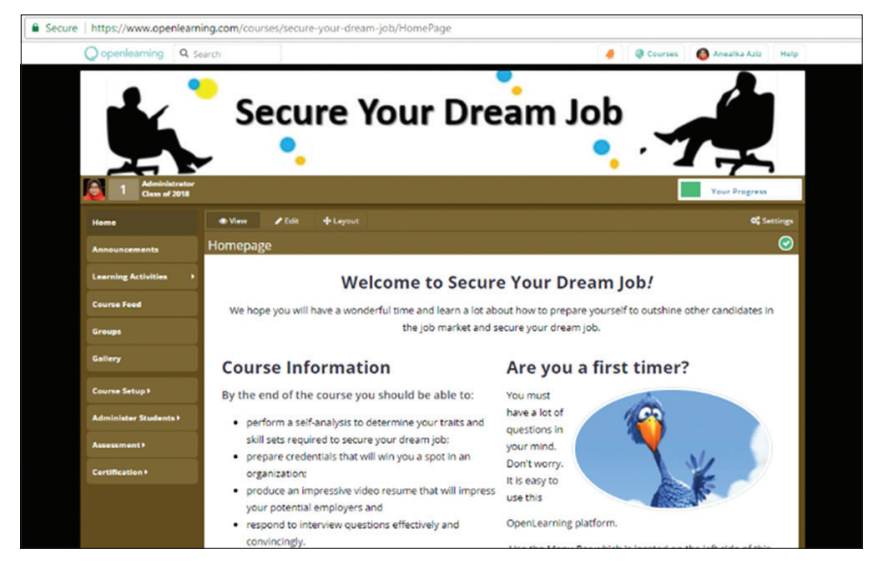

Figure 3: Interface of the Course Home Page

reflect and share contents, links, audio, video and pictures. Figure 6 shows a sample of activities in Padlet.

Once they have completed the task, students are required to prepare a resume. A group discussion about the different types of resume and the essential components of a resume is conducted. The OL platform is used for this purpose. Students are given a list of reading titles related to resume writ- ing and tips for effective resume. Besides the list, students are encouraged to do their own search on effective resume and share the links in the OL platform. Based on the information gathered, an onsite discussion to justify reasons to have or not to have certain components is conducted. An individual resume will be prepared and uploaded in the respective folder. Figure 7 shows the learning activities for Module 2: Resume.

The next module is about creating video resume. At the end of this module, students should be able to determine the essential components of an effective video resume and create their own video resume. A reading list and sample video resumes are provided to prepare the students for the activities. Students are encouraged to share new articles or video resumes that they think can add values to their own video resumes. A discussion on the criteria of an effective video resume is conducted and a checklist is created based on the discussion. Then, the students are required to evaluate some video resumes based on the checklist. Figure 8 shows the learning activities of Module 3: Video Resume.

The second activity is a practice before the students produce their own video resume. In this activity, the students are required to work in a group to compete for a 


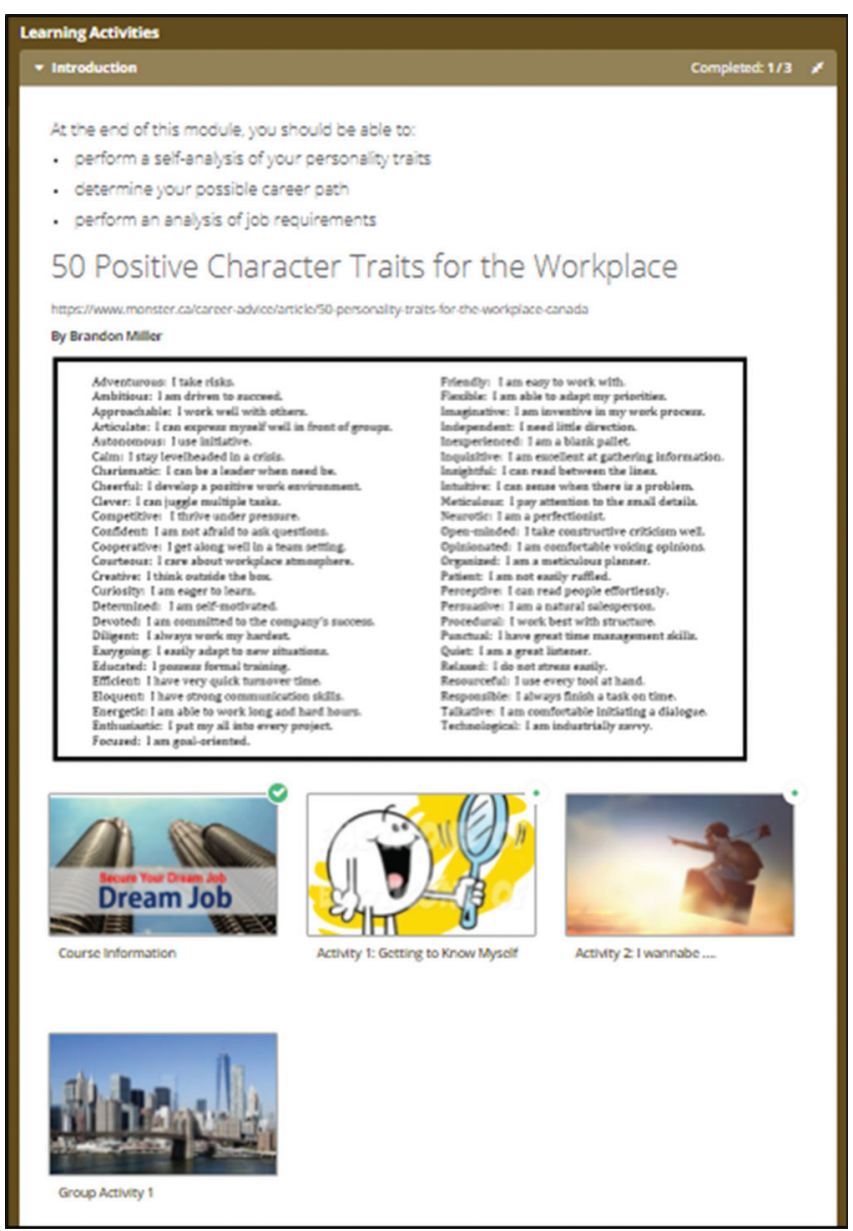

Figure 4: Sample Learning Activities in a Module

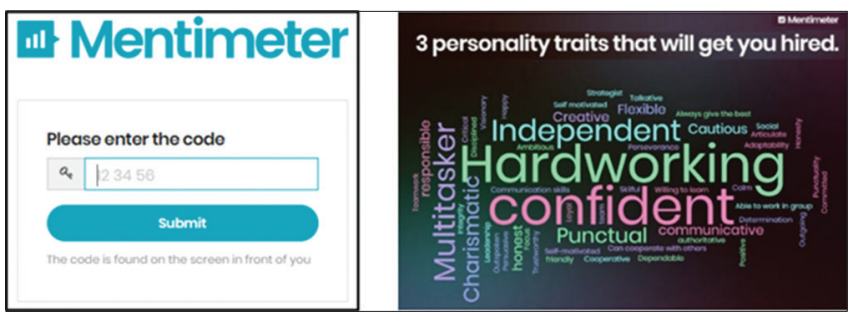

Figure 5: Interface of Mentimeter Voting and Output of Voting

hypothetical task of a fun-raising organizer. The groups are required to create a one-minute promotional video of why their group should be granted the task. The videos will be uploaded in Activity 2 folder. The videos are to be peer-evaluated in the following class. Each group receives a set of pictures which act as triggers to open all the videos in their smartphones. Using a digital apps named HP Reveal (https://studio.hpreveal.com), students scan the triggers and watch the videos in their smaller group setting. Feedback from this activity are useful in creating their own video resume. All video resumes will be uploaded in the respective folder. Figure 9 shows the triggers to launch the students' videos.

The next module is Interview. At the end of this module, students should be able to differentiate the different types of interview, list commonly asked questions in interview, take part in a focus group and one-to-one interview. Like the

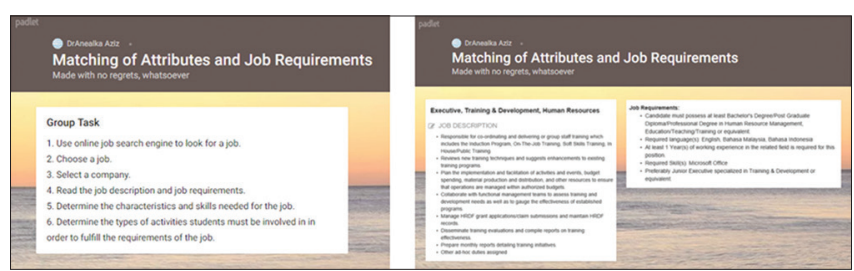

Figure 6: An Activity on Padlet

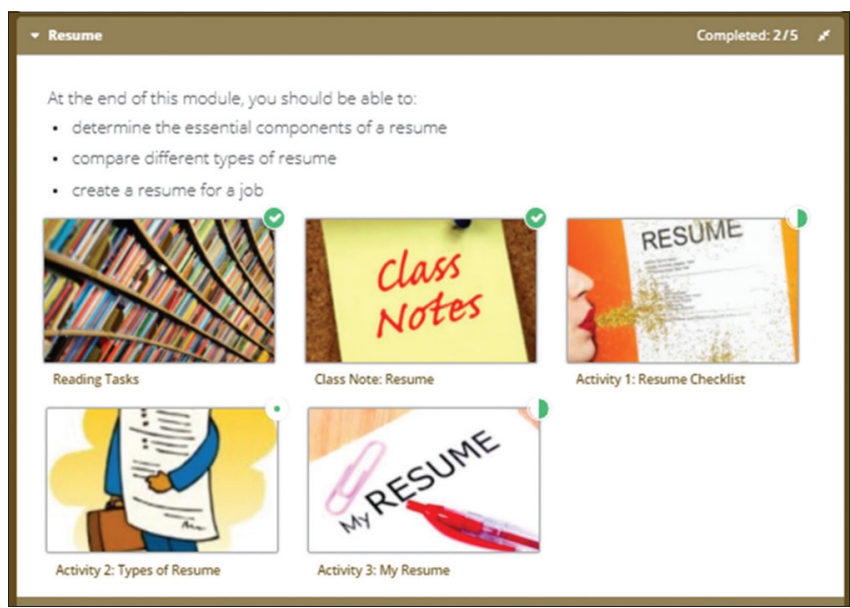

Figure 7: Learning Activities in Module 2: Resume

previous module, a reading list is provided for the students to prepare themselves before they come to class. One of the activities require students to discuss a certain issue and post their opinion in the OL platform. Figure 10 shows sample responses from the students. The class instructor summarizes the discussion after all responses are being discussed. The interviews are parts of the course assessment; therefore, they are done face-to face in a suitable assessment venue.

The course provides rewards in terms of badges to the students for their participation and creativity in completing the tasks. These badges are to motivate students to be active learners and creative in preparing their printed and video resume and portfolio. Figure 11 shows the types of badges awarded to the students.

Having a flipped classroom enables class instructors to be very flexible and creative in designing activities. There are many digital tools available to support onsite and online learning. These activities need to be guided and feedback from the class instructors is also important which can be done both online and onsite whenever required.

In terms of assessment, several tools are being used depending on the tasks. Online quizzes using Kahoot! and Socrative are used to check students' understanding of the basic concepts related to the course. Figure 12 shows the student login interface of Kahoot! and Socrative.

\section{Students' Feedback}

After completing the course, a survey was administered. The purpose of the survey was to get the students' feedback on their experience being taught using the flipped classroom approach adopted by the class instructor. All 23 students participated in the survey. 
$60.9 \%$ of the students found the learning of the first module on Resume as very interesting, $30.4 \%$ found it as interesting and $8.6 \%$ found it as average. For the second module, Video Resume, $73.9 \%$ found that the learning process was very interesting, $17.4 \%$ claimed it as interesting, while $8.7 \%$ claimed it as average. As for the last module, Interview, $69.6 \%$ claimed it as interesting, $26.1 \%$ claimed it as interesting, while $4.3 \%$ claimed it as average.

In terms of the usefulness of the content, $52.2 \%$ of the students said the first module was very useful, 34.8\% claimed it as useful, $8.7 \%$ claimed it as average and $4.3 \%$ said it as not useful. As for the second module, $60.9 \%$ of the students said the first module was very useful, $30.5 \%$ claimed it as useful, $4.3 \%$ claimed it as average not useful respectively. The respond for the last module shows $56.5 \%$ of the students claimed it as very useful, $26.2 \%$ claimed it as useful, $13.0 \%$ claimed it as average and $4.3 \%$ claimed it as not useful.

Students also said that they are comfortable learning in the class and they found the flipped learning approach adopted by the class instructor as enjoyable and they felt confidence to take part actively in the learning sessions. These findings of the survey show that $82.6 \%$ of the students claimed that they felt very comfortable while $17.4 \%$ claimed that they felt

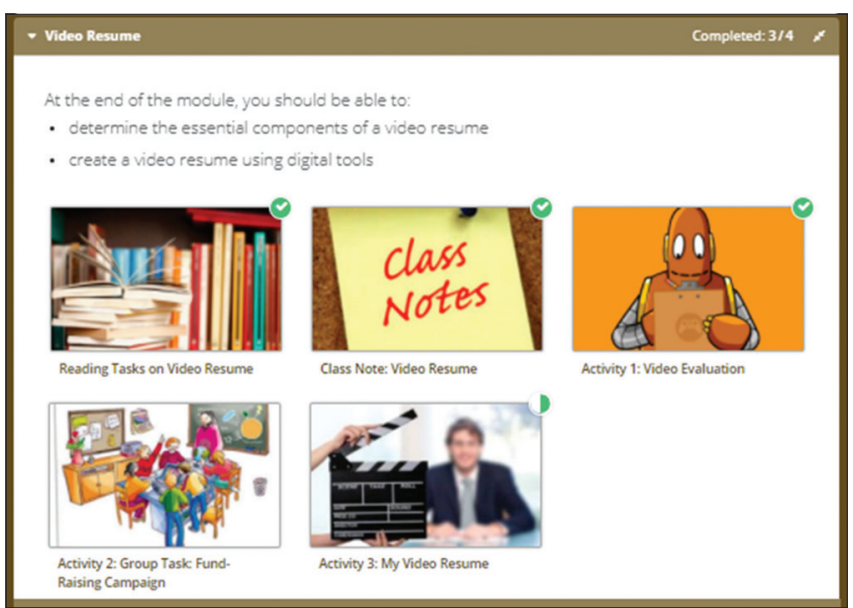

Figure 8: Learning Activities in Module 3: Video Resume comfortable learning in such setting. $78.3 \%$ said they always enjoyed learning in the classroom, while $17.4 \%$ said they often enjoyed the learning in the classroom and $4.3 \%$ said sometimes they enjoy learning in such classroom. When students are comfortable learning in the classroom, they usually feel confident to take part in the classroom activities. This can be seen in the findings of the study. $47.8 \%$ of the students said they always felt confident to take part in the classroom activities while the remaining $52.2 \%$ said that they often felt confident taking part in the class activities.

Generally, students enjoyed the approach used by the class instructor in teaching the course. They did not feel threaten in the class hence the active participation throughout the whole learning experience. They also claimed they learned a lot about the course and suggested other courses to be conducted similarly. The only problem faced by the students was the instability of the internet connection in their classroom. They had to resort to their own broadband when it came to individual responses to questions or tasks. Despite having this problem, students continued taking part actively in the class activities until the end of the semester.

\section{CONCLUSION}

The changes that take place in Education 4.0 really describes the learning preference of the Gen $\mathrm{Z}$ students. Based on the sharing session above, it is not impossible for a language course to adapt to the changes that are brought by the IR4.0 wave. It is about time for class instructors to consider integrating more current technologies in their teaching methodology. The students that they have now have different preference than students that they had 10 years ago. Integrating more current technologies will make the instructors more creative in designing their lessons, thus making the learning more interesting. Learning can also be more effective as the way it is delivered matches the Gen Z students' preferences. The flipped classroom approach has enable the class instructor to plan the learning activities in such a way that can support the Social Emotional Learning of the students
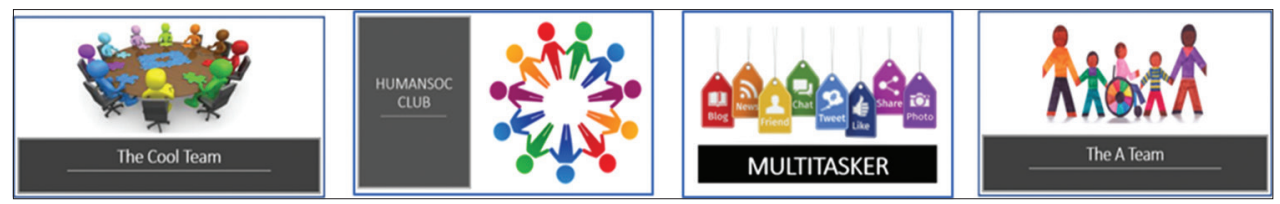

Figure 9: Triggers to Launch Students' Videos
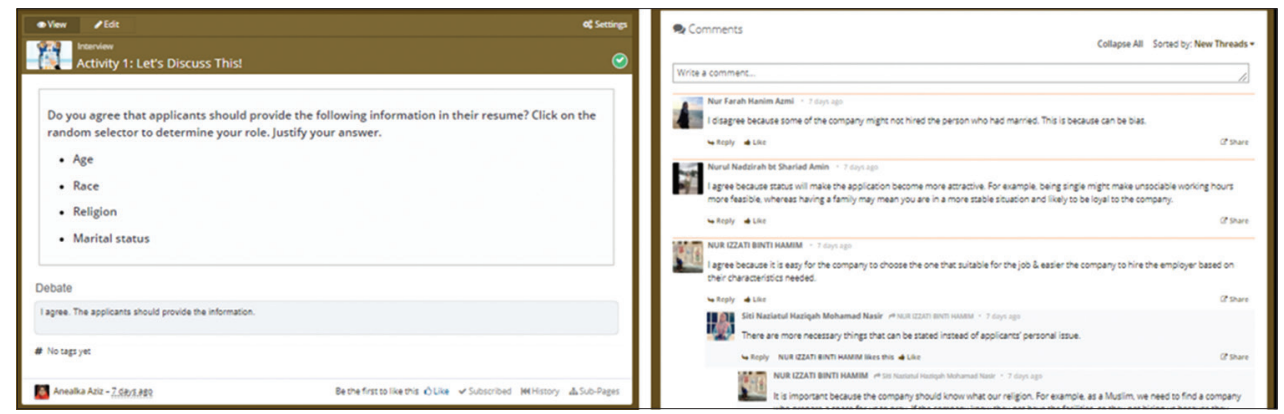

Figure 10: Sample Students' Responses for the Discussion Activity 


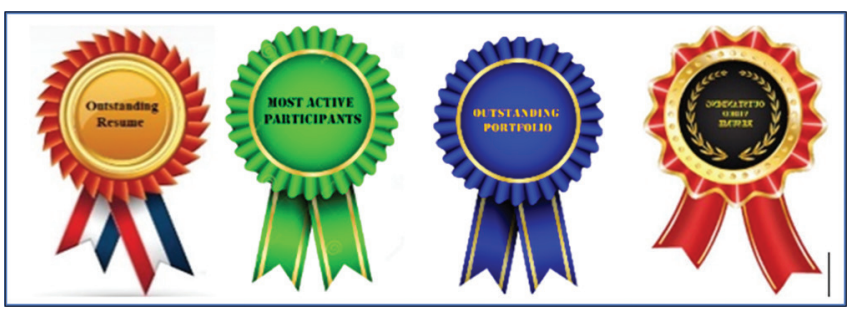

Figure 11: Badges for Students

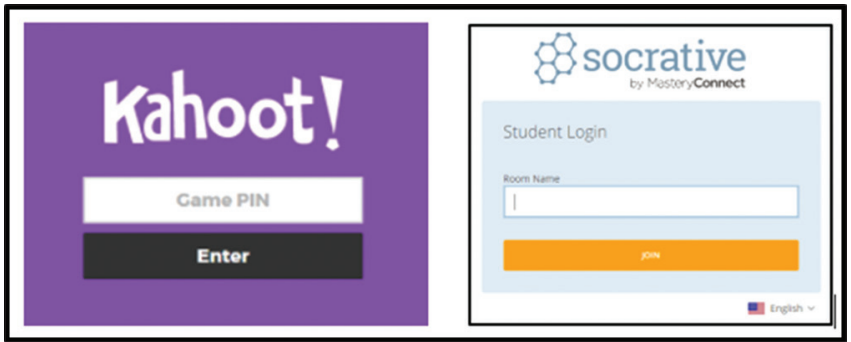

Figure 12: Login Interface of Kahoot! and Socrative for Students

as well. The learning activities in this course incorporate the 14 strategies for SEL as outlined in the World Economic Forum report (2016b). In short, instructors should welcome this new wave of Education 4.0 as not only the students will benefit from it, language instructors can also have more flexibility is designing their lessons creatively.

\section{REFERENCES}

Diwan, P. (2017). Is Education 4.0 an imperative for success of $4^{\text {th }}$ Industrial Revolution? Accessed from https://medium.com/@pdiwan/is-education-4-0-an-imperative-for-success-of-4th-industrial-revolution-50c31451e8a4
Dunwill, E. (2016). 4 changes that will shape the classroom of the future: Making education fully technological. Accessed from https://elearningindustry.com/4-changes-will-shape-classroom-of-the-future-making-education-fully-technological.

Education technology and Mobile Learning (2016). 9 fundamental digital skills for $21^{\text {st }}$ century teachers. Accessed from https://www.educatorstechnology. com/2016/12/9-fundamental-digital-skills-for-2 $1^{\text {st }}$. html

Fisk, P. (2017). Education 4.0 ... the future of learning will be dramatically different, in school and throughout life. Retrieved from http://www.thegeniusworks.com/2017/01/future-education-young-everyone-taught-together

Kozinski, S. (2017). How generation $\mathrm{Z}$ is shaping the change in education. Retrieved from https:/www.forbes.com/ sites/sievakozinsky/2017/07/24/how-generation-z-isshaping-the-change-in-education/\#304059746520

Shwab, K. (2016). The Fourth Industrial Revolution: what it means, how to respond. Accessed from https://www. weforum.org/agenda/2016/01/the-fourth-industrial-revolution-what-it-means-and-how-to-respond

Soffel, J. (2016). What are the $21^{\text {st }}$ century skills every student needs? Accessed from https://www.weforum.org/ agenda/2016/03/21 st-century-skills-future-jobs-students

World Economic Forum (2016a). Chapter 1: The future of jobs and skills. Accessed from http://reports.weforum. org/future-of-jobs-2016/chapter-1-the-future-of-jobsand-skills

World Economic Forum Report (2016b). New Vision for Education: Fostering social and emotional learning through technology. 